\title{
Effect of milking frequency on lactation persistency and mammary gland remodeling in mid-lactation cows ${ }^{1}$
}

\author{
P. Bernier-Dodier, ${ }^{*}$ L. Delbecchi, $\dagger^{2}$ G. F. Wagner, $\ddagger$ B. G. Talbot, ${ }^{*}$ and P. Lacasse $\dagger^{3}$ \\ *Département de Biologie, Faculté des Sciences, Université de Sherbrooke, Sherbrooke, Quebec, Canada J1K 2R1 \\ †Dairy and Swine Research and Development Centre, Agriculture and Agri-Food Canada, PO Box 90 STN Lennoxville, Sherbrooke, Quebec, \\ Canada J1M 1 Z3 \\ ‡Department of Physiology and Pharmacology, Schulich School of Medicine and Dentistry, University of Western Ontario, London, Ontario, \\ Canada N6A 5C1
}

\begin{abstract}
The objective of this study was to evaluate the effect of milking frequency on milk production and composition, mammary cell proliferation, apoptosis, and gene expression. For this investigation, 10 Holstein cows that were being milked twice a day in mid lactation were selected. To study the effect of differential milking, 2 quarters were milked once daily and the other 2 were milked thrice daily for $8 \mathrm{wk}$. After that period, twicedaily milking was resumed for all quarters, and data were collected for an additional 6 wk. Mammary gland biopsies were taken 1 wk before differential milking (wk -1) and after 4 and 8 wk of differential milking. Milk samples were collected weekly throughout the experiment. Once-daily milking resulted in an immediate reduction in milk yield, whereas thrice-daily milking resulted in an increase in milk yield. During differential milking, the daily milk yield of the quarters milked once daily declined by $0.54 \mathrm{~kg} / \mathrm{wk}$, on average, but remained constant in the quarters milked thrice daily. Part of the difference in milk yield between the glands pairs persisted after twice-daily milking was reinitiated. In the quarters milked once daily, milk BSA concentration increased, indicating an increase in tight junction leakiness, and zymographic analysis of milk enzymes showed increased activity of several proteases. Reducing the milking frequency also increased mammary cell apoptosis and, surprisingly, mammary cell proliferation. Interestingly, milk concentrations of stanniocalcin-1 and insulin-like growth factor-I and mammary gland expression of several genes were also modulated by milking frequency. For example, expression of insulinlike growth factor I receptor was downregulated during once-daily milking. Last, expression of the short and

\footnotetext{
Received April 23, 2009.

Accepted October 7, 2009.

${ }^{1}$ Dairy and Swine Research and Development Centre Contribution

${ }^{2}$ Deceased

${ }^{3}$ Corresponding author: lacassep@agr.gc.ca
} No. 1023.
\end{abstract}

long isoforms of the prolactin receptor and of CSN2 ( $\beta$-casein) were upregulated during thrice-daily milking. Taken together, these data suggest that milking frequency not only affects mammary gland remodeling and the expression of paracrine factors but also modulates hormone sensitivity.

Key words: differential milking, apoptosis, prolactin, involution

\section{INTRODUCTION}

Milk production is a function of the number of mammary epithelial cells and their secretory activity. Capuco et al. (2001) proposed that the decrease in milk production following peak lactation in dairy cows is largely caused by mammary epithelial cell loss. The events leading to this cell loss are poorly understood, however, and a better understanding of this process could be beneficial for dairy producers by suggesting new ways to improve lactation persistency.

It is well known that milking frequency directly influences milk yield (Hale et al., 2003; Nørgaard et al., 2005). Increasing the milking frequency (IMF) in early lactation increases milk yield and has a carryover effect that persists when the period of IMF is finished (Hale et al., 2003; Wall and McFadden, 2007). Conversely, reducing the milking frequency has a negative effect on milk production (Erdman and Varner, 1995; O'Brien et al., 2002). Moreover, these effects are locally regulated, as has been demonstrated in several half-udder studies (Stelwagen and Knight, 1997; Sorensen et al., 2001; Wall and McFadden, 2007). Several hypotheses have been proposed to explain the positive effect of IMF (reviewed recently by Wall and McFadden, 2008), but the exact mechanism remains to be elucidated.

Given that milking frequency modulates lactation persistency, a detailed characterization of the effects of milking frequency could provide relevant information about the regulation of lactation persistency. Accordingly, the objective of this study was to characterize the effects of IMF (thrice-daily milking) and reduced milk- 
ing frequency (once-daily milking) on milk production and composition as well as on mammary cell proliferation, apoptosis, and gene expression.

\section{MATERIALS AND METHODS}

\section{Animals and Experimental Procedures}

For this study, 10 mid-lactation Holstein cows (7 primiparous and 3 multiparous) averaging $169 \pm$ 9 DIM were used. The cows were housed at Agriculture and Agri-Food Canada's Dairy and Swine Research and Development Centre (Sherbrooke, Quebec) and animal use was conducted in accordance with Canadian Council on Animal Care guidelines. Before the initiation of treatments, all quarters were milked twice daily $(\mathbf{2} \times$; wk $-3,-2$, and -1 ; pretreatment period). During the following $8 \mathrm{wk}$ (treatment period), the left hindquarters and right forequarters were milked once daily $(\mathbf{1} \times)$, whereas the right hindquarters and left forequarters were milked thrice daily $(\mathbf{3} \times)$. After the treatment period, $2 \times$ milking was resumed on all quarters and data were collected for an additional 6 wk (wk 9 to 14; posttreatment period). The cows were milked at 0700 and $1900 \mathrm{~h}$ during $2 \times$ milking. During differential milking, the $3 \times$ quarters were milked at 0700, 1300, and $1900 \mathrm{~h}$ (intervals of 6,6 , and $12 \mathrm{~h}$ ), whereas the $1 \times$ quarters were milked only at $1900 \mathrm{~h}$. Milk was harvested using individual quarter milking units and production was recorded for each quarter. For wk -2 to 10 , the daily milk yield was calculated as the average of daily production recorded on each day of the corresponding week. For wk $-3,11,12,13$, and 14 , the daily milk yield was based on $1 \mathrm{~d}$ of measurements per week. Milk samples from each quarter were taken $1 \mathrm{~d}$ per week at each milking during that day. For each of those samples, milk lactose, protein, and fat concentrations were determined by near-infrared spectrophotometry, and SCC was determined by an automatic cell counter in a commercial laboratory (Valacta Inc., Ste-Anne-deBellevue, Quebec, Canada). In addition, aliquots of the milk samples were defatted by centrifugation (15 min, $\left.1,000 \times g, 4^{\circ} \mathrm{C}\right)$ and frozen. In wk $-1,4$, and 8, mammary biopsies from both hindquarters were taken as described by Miller et al. (2006). Biopsies were immediately cut into several pieces that were either snap-frozen in liquid nitrogen (200-mg pieces) or fixed overnight at $4^{\circ} \mathrm{C}$ in $10 \%$ neutral buffered formalin (50-mg pieces). The following day, the fixed tissues were dehydrated with a series of graded ethanol baths, cleared in xylene, and embedded in paraffin. Tissue sections $4 \mu \mathrm{m}$ thick were then cut and mounted on Superfrost Plus slides (Fisher Scientific Inc., Nepean, Ontario, Canada).

\section{Milk BSA Concentration}

The concentration of BSA in milk was measured as an indicator of mammary tight junction permeability. The BSA concentration was determined as described by Tremblay et al. (2009). Forequarter milk samples taken at the $1900 \mathrm{~h}$ milking were used for this analysis.

\section{Milk Gelatinase Activity}

Because milk proteases may affect mammary gland remodeling, milk gelatinase activities were determined by gelatin zymography. Zymography was performed as described by Tremblay et al. (2009) with the exception that $12 \%$ polyacrylamide gels $(1.5 \mathrm{~mm}$ thick) were used. Forequarter milk samples taken at the $1900 \mathrm{~h}$ milking were used for this analysis.

\section{Milk IGF-I and Stanniocalcin-1 Concentrations}

Measurement of IGF-I concentrations in defatted milk was performed using a double-antibody RIA as described by Abribat et al. (1993) with the exception that the anti-IGF-I antiserum (\#AFP4892898) was obtained from the National Hormone and Peptide Program, and the secondary anti-rabbit antibody was purchased from Linco Research Inc. (St. Charles, MO). Milk stanniocalcin-1 (STC-1) concentration was determined by RIA as described by Niu et al. (2000). Forequarter milk samples taken at the $1900 \mathrm{~h}$ milking were used for this analysis.

\section{Terminal Deoxynucleotidyl Transferase dUTP Nick-End Labeling Assay}

Mammary cell apoptosis was measured using terminal deoxynucleotidyl transferase dUTP nick-end labeling (TUNEL) with the DeadEnd Colorimetric TUNEL System (Promega Corp., Madison, WI). This assay was performed as recommended by the manufacturer. Cells were then counterstained with a methyl green solution and, following dehydration, mounted with Permount (Fisher Scientific Inc.). Tissue sections were viewed with a Nikon Eclipse 50i microscope (Nikon Corp., Tokyo, Japan) fitted with a QImaging Go-3 digital camera (QImaging Corp., Surrey, British Columbia, Canada). ImageJ software (National Institutes of Health, Bethesda, MD) was used to quantify mammary cell apoptosis in at least 5 nonoverlapping fields for each biopsy.

\section{Ki-67 Immunohistological Detection}

Mammary cell proliferation was evaluated by the detection of the Ki-67 antigen using the Histostain- 
Table 1. Primers used during real-time PCR

\begin{tabular}{|c|c|c|c|c|}
\hline Gene $^{1}$ & $\begin{array}{l}\text { GenBank accession } \\
\text { number }\end{array}$ & Primer $\left(5^{\prime}\right.$ to $\left.3^{\prime}\right)$ & Orientation & $\begin{array}{l}\text { Amplicon } \\
\text { length (bp) }\end{array}$ \\
\hline$A C T G 1$ & BC147868 & $\begin{array}{l}\text { CGCACCACTGGCATTGTCAT } \\
\text { TCCAAGGCGACGTAGCAGAG }\end{array}$ & $\begin{array}{l}\text { Forward } \\
\text { Reverse }\end{array}$ & 227 \\
\hline$B C L 2$ & U92434 & $\begin{array}{l}\text { ACGCCTTTGTGGAGCTGTATG } \\
\text { CCTTCAGAGACAGCCAGGAGA }\end{array}$ & $\begin{array}{l}\text { Forward } \\
\text { Reverse }\end{array}$ & 69 \\
\hline$I G F 1$ & AF404761 & $\begin{array}{l}\text { CCTGCGCAATGGAATAAAGTC } \\
\text { AGGCAAAAAGAAATCCAGGGA }\end{array}$ & $\begin{array}{l}\text { Forward } \\
\text { Reverse }\end{array}$ & 83 \\
\hline$I G F 1 R$ & X54980 & $\begin{array}{l}\text { CAACCTCCGGCCTTTTACTCT } \\
\text { GCTGCAGCCAAGCTTCTCA }\end{array}$ & $\begin{array}{l}\text { Forward } \\
\text { Reverse }\end{array}$ & 76 \\
\hline$I G F B P 5$ & NM001105327 & $\begin{array}{l}\text { AAAGAGCTACCGCGAGCAAG } \\
\text { CTGCCATCTCGGAGGTGGT }\end{array}$ & $\begin{array}{l}\text { Forward } \\
\text { Reverse }\end{array}$ & 77 \\
\hline$M Y C$ & AF519455 & $\begin{array}{l}\text { GACCAGATCCCAGAGTTGGA } \\
\text { GAGCTTTTGCTGCTCTGCTT }\end{array}$ & $\begin{array}{l}\text { Forward } \\
\text { Reverse }\end{array}$ & 105 \\
\hline PTHLH & BC129411 & $\begin{array}{l}\text { CCTGCTCCCAACACCAAGA } \\
\text { GTCAGGTATTTGCCCTCATCATC }\end{array}$ & $\begin{array}{l}\text { Forward } \\
\text { Reverse }\end{array}$ & 65 \\
\hline STC1 & NM176669 & $\begin{array}{l}\text { AAGCTGAAAGTCCTCCTCAGGAA } \\
\text { TTTGCTGAGGCTGTGATTGC }\end{array}$ & $\begin{array}{l}\text { Forward } \\
\text { Reverse }\end{array}$ & 114 \\
\hline
\end{tabular}

${ }^{1} A C T G 1=$ actin; $B A X=\mathrm{Bcl}$-associated $\mathrm{X}$ protein; $B C L 2=\mathrm{B}$-cell $\mathrm{CLL} /$ lymphoma $2 ; C S N 2=\beta$-casein; $I G F 1=$ insulin-like growth factor $1 ;$ $I G F 1 R=$ insulin-like growth factor 1 receptor; IGFBP $=$ insulin-like growth factor binding protein $5 ; M Y C=\mathrm{c}-\mathrm{Myc} ; P R L R($ short $)=$ prolactin receptor, short isoform; PRLR (long) = prolactin receptor, long isoform; PTHLH = parathyroid hormone-like hormone (PTHrP); $S T C 1$ $=$ stanniocalcin-1.

Plus kit and a mouse anti-Ki-67 antibody (Invitrogen Corp., Burlington, Ontario, Canada). This assay was performed as recommended by the manufacturer with the exception that rehydrated tissues were heated in a microwave in citrate buffer and washes were carried out with PBS $0.05 \%$ Tween 20 . After detection, cells were counterstained with hematoxylin (Invitrogen Corp.), dehydrated, and mounted with Permount (Fisher Scientific Inc.). Tissue sections were viewed with a Nikon Eclipse 50i microscope fitted with a QImaging Go-3 digital camera. Mammary cell proliferation was quantified by analysis of at least 5 nonoverlapping fields for each biopsy using Image J software.

\section{Real-Time PCR}

Total RNA was extracted from mammary biopsies using Trizol reagent (Invitrogen Corp.) according to the manufacturer's instructions. The quality of RNA was verified by examination after agarose gel electrophoresis. Treatment with DNase and reverse transcription were performed as described by Delbecchi et al. (2005). The resulting cDNA was diluted 1:50 in water, and $5 \mu \mathrm{L}$ was used for amplification and quantification with the Power SYBR Green PCR Master Mix (Applied Biosystems Inc., Foster City, CA). AmpErase UNG (Applied Biosystems Inc.) was added to the mix
(0.1 U per $20-\mu \mathrm{L}$ reaction) and primers (Applied Biosystems Inc.) were used at a concentration of $300 \mathrm{n} M$. Primer sequences are presented in Table 1. The PCR conditions consisted of $2 \mathrm{~min}$ at $50^{\circ} \mathrm{C}, 10 \mathrm{~min}$ at $95^{\circ} \mathrm{C}$, and 40 cycles of $15 \mathrm{~s}$ at $95^{\circ} \mathrm{C}$ and $60 \mathrm{~s}$ at $60^{\circ} \mathrm{C}$ using the 7500 Fast Real-Time PCR System (Applied Biosystems Inc.). A standard curve made with serial dilutions of a pool of reverse transcripts ( 8 samples from this study) was used to quantify samples. Gene expression was normalized with the values obtained for the $A C T G 1$ (actin) gene.

\section{Statistical Analysis}

Statistical analyses were performed using the MIXED procedure (SAS Institute Inc., Cary, NC) as repeated measurements. The subject was cow(milking frequency) and cow was included as a fixed effect in the model. For the analysis of SCC, data were $\log _{10}$-transformed before analysis. Effects of treatment relative to the pretreatment period were assessed by analyzing the effect of time within each treatment. Statistical analysis of the real-time PCR results was performed in accordance with the recommendations of User Bulletin \#2 for the ABI Prism 7700 Sequence Detection System (December 11, 1997; Applied Biosystems Inc.). Briefly, an ANOVA on $\log _{10}$ of the values normalized individually in relation 


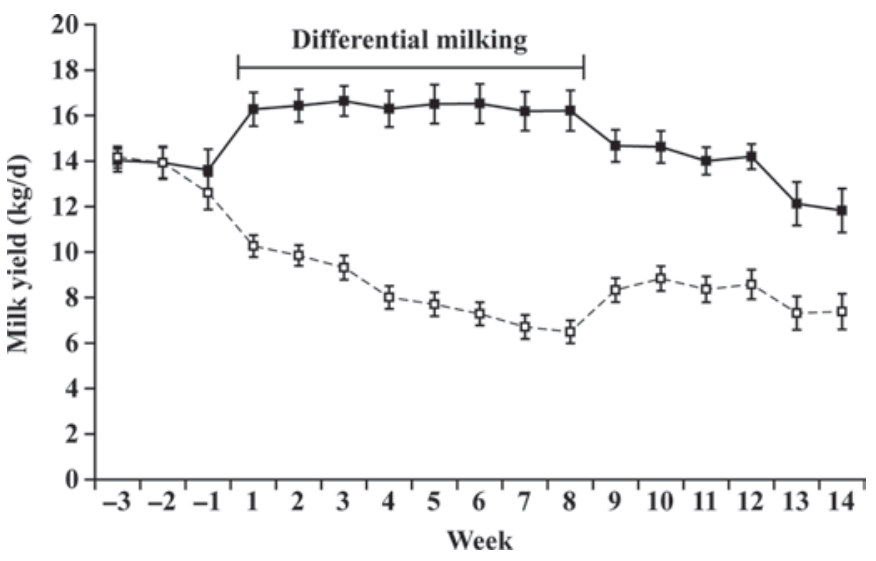

Figure 1. Effect of differential milking on daily milk yield. Quarters were milked once $(1 \times ; \square$, dashed line) or thrice $(3 \times ; \boldsymbol{\square}$, solid line) daily from wk 1 to 8 and twice daily before and after the differential milking period. Quarters milked $3 \times$ had higher milk yield than quarters milked $1 \times$ during and after differential milking $(P<0.001)$. Data are presented as least squares means \pm SEM of each pair of glands.

to $A C T G 1$ was performed using the MIXED procedure of SAS with repeated measurements. Protease activities were analyzed with the GLIMMIX procedure of SAS, and there was, therefore, no standard error of the mean. Results were considered statistically significant when $P<0.05$.

\section{RESULTS}

At the beginning of the experiment, all quarters were milked $2 \times$ and pairs of glands had similar milk yields $(P>0.15$; Figure 1). During differential milking, the quarters milked $3 \times$ produced more milk $(P<0.001)$ than those milked $1 \times$. Moreover, the milk yield of the $1 \times$ gland pair declined $(P<0.001)$ by $0.54 \mathrm{~kg} / \mathrm{d}$ per week, whereas the yield of the $3 \times$ gland pair remained stable $(P>0.15)$ during the treatment period. In the last week of treatment (wk 8), the milk yield of the $1 \times$ quarters was only $40 \%$ of that of the $3 \times$ quarters. A difference persisted even after $2 \times$ milking was resumed (wk 9 to 14; $P<0.001$ ). During the first posttreatment week (wk 9), the milk production of the $1 \times$ quarters was $57 \%$ of that of the $3 \times$ quarters and in the sixth posttreatment week (wk 14), it was $62 \%$.

Before differential milking began, milk composition was similar in all quarters $(P>0.15)$. Milk lactose concentration (Figure 2A) decreased during $1 \times$ milking $(P<0.001)$ and was lower than that of the $3 \times$ quarters during $(P<0.001)$ and after differential milking $(P<$ $0.001)$. Lactose yield was lower $(P<0.001)$ in the $1 \times$ quarters compared with the $3 \times$ quarters, averaging 316 \pm 10 and $746 \pm 10 \mathrm{~g} / \mathrm{d}$ for $1 \times$ and $3 \times$ (total per gland pair), respectively, during differential milking, and 365 \pm 20 and $654 \pm 20 \mathrm{~g} / \mathrm{d}$, respectively, after differential milking (data not shown). Content in fat (Figure 2B) of the milk from the $1 \times$ quarters increased gradually $(P<0.01)$ and was higher than that of the $3 \times$ quarters in the wk 6 and 8 of treatment $(P<0.05)$. Protein concentration was unaffected by the treatments, averaging $3.55 \%$ in the $1 \times$ quarters and $3.56 \%$ in the $3 \times$ quarters (data not shown). Fat and protein yields were higher in the $3 \times$ quarters than in the $1 \times$ quarters $(P<$ $0.001)$ during and after differential milking, reflecting the higher milk production of these quarters (data not shown). The milk of the $1 \times$ quarters had higher SCC than the milk of the $3 \times$ quarters during $(P<0.05)$ and after $(P<0.01)$ differential milking (Figure 3). However, the total number of somatic cells $(\mathrm{SCC} \times$ milk production) was unaffected by the treatments $(P$ $>0.15$; data not shown).

Before differential milking, BSA concentration was slightly higher in the milk from the quarters to be milked $1 \times(P<0.05$; Figure 4$)$ compared with those to be milked $3 \times$. Within the first week of differential milking, milk BSA concentration decreased in the $3 \times$ quarters $(P<0.05)$ but increased markedly in the $1 \times$ quarters $(P<0.001)$. Consequently, the milk of the $1 \times$ quarters had higher BSA content during the treatment period $(P<0.0001)$. During the posttreatment period, milk BSA concentration remained higher in the $1 \times$ quarters than in the $3 \times$ quarters $(P<0.001)$, but to a lesser extent than during the treatment period.

The presence of several proteases in milk was evaluated by gelatin zymography (Figure 5). Based on the apparent molecular weight at which the gelatinolytic activities were detected and on the results obtained by Raulo et al. (2002), we identified 3 matrix metalloproteinases (MMP), namely MMP-1, MMP-2, and MMP9 , as being abundant in our samples. Before differential milking, no differences in the activities of these proteases were observed $(P>0.15)$. However, $1 \times$ milking caused an increase in the activity of MMP-1 and MMP-9 $(P<$ 0.001 and $P<0.01$, respectively). Therefore, their activity was higher in the milk from the $1 \times$ quarters than in that of the $3 \times$ quarters during $(P<0.01)$ and after $(P<0.01)$ the treatment period. Moreover, milk MMP2 activity was higher in $1 \times$ quarters than in the $3 \times$ quarters in wk $6(P<0.05)$ and $7(P<0.01)$, whereas a trend was apparent in wk $8(P=0.07)$.

Once-daily milking caused an increase in milk concentration of both IGF-I and STC-1 (Figure 6). This resulted in higher levels of both these hormones in the $1 \times$ quarters compared with the $3 \times$ quarters (IGF-I, $P$ $<0.0001$; STC-1, $P<0.01$ ), a difference that persisted beyond the treatment period (IGF-I, $P<0.001$; STC-1, $P<0.01$ ). Before differential milking, IGF-I concentration was already higher in the milk from the quarters to be milked $1 \times$ than in the milk from those to be milked 

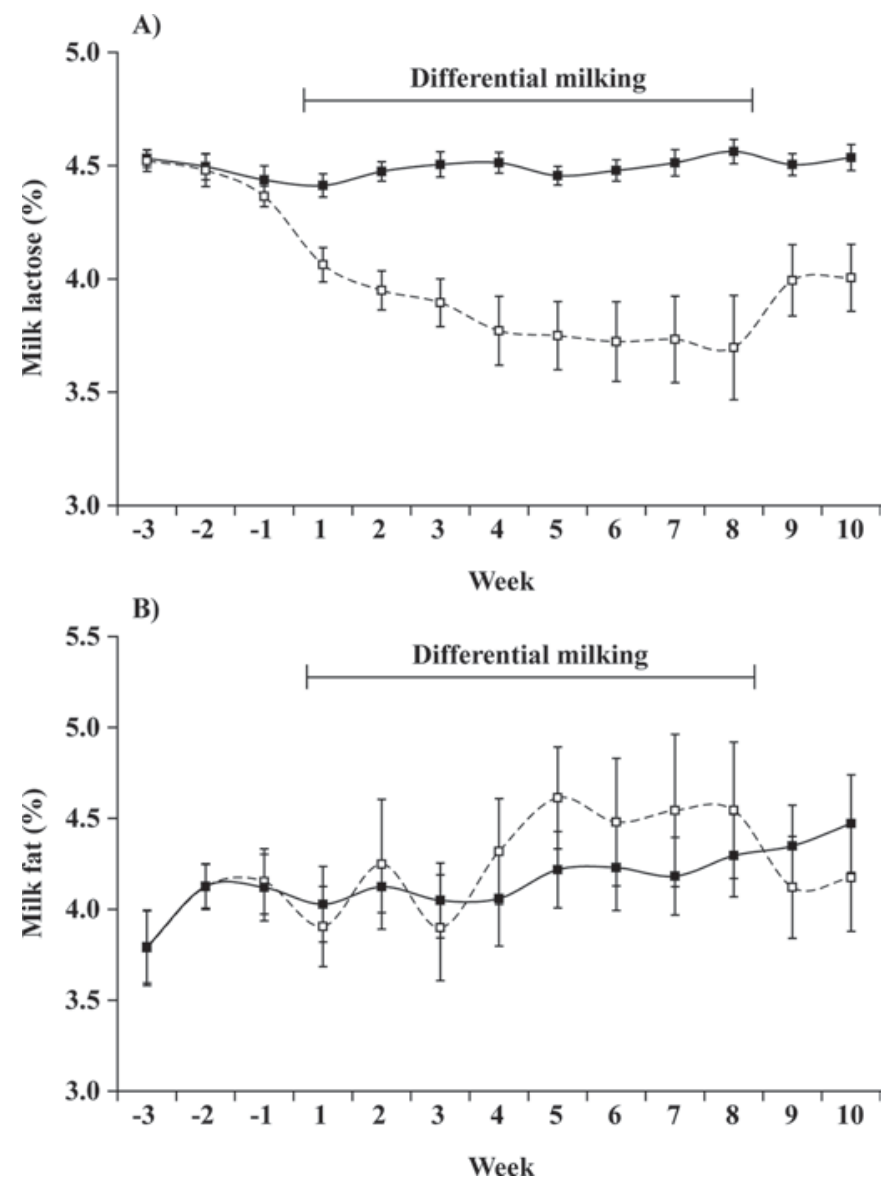

Figure 2. Effect of differential milking on milk lactose (A) and fat (B) concentrations. Quarters were milked once $(1 \times ; \square$, dashed line) or thrice $(3 \times ; \mathbf{\square}$, solid line) daily from wk 1 to 8 and twice daily before and after the differential milking period. Milk lactose concentration was lower in the $1 \times$ quarters than in the $3 \times$ quarters during and after differential milking $(P<0.001)$. In wk 6 and 8 of treatment, fat content was higher in the milk from the $1 \times$ quarters than that of the milk from the $3 \times$ quarters $(P<0.05)$. Data are presented as least squares means \pm SEM.

$3 \times(P<0.05)$, whereas milk STC-1 content was similar in all quarters $(P>0.15)$.

Mammary cell apoptosis was measured by TUNEL assay in tissues collected in wk $-1,4$, and 8 (Figure 7A). Apoptosis rate was similar in both groups before the treatments $(P>0.15)$ and milking $1 \times$ increased the apoptosis rate $(P<0.05)$. In wk 4 , it was 2.2 times greater in the $1 \times$ quarters than in the $3 \times$ quarters $(P$ $<0.05)$. Apoptosis rate was similar in $1 \times$ and $3 \times$ quarters in wk $8(P>0.15)$. Mammary cell proliferation was evaluated by immunohistological detection of the Ki-67 antigen (Figure 7B). Proliferation rate was similar in both groups before treatment. Once-daily milking increased proliferation in the $1 \times$ glands $(P<0.001)$ and was 2.4 and 2.8 times higher in the $1 \times$ quarters than in the $3 \times$ quarters in wk $4(P<0.05)$ and wk 8 $(P<0.01)$, respectively.
The mammary gland expression of several genes was evaluated by real-time PCR from tissues taken by biopsy in wk $-1,4$, and 8 (Table 2 ). The expression of CSN2 ( $\beta$-casein) decreased with time in the $1 \times$ quarters (time $\times$ treatment; $P<0.001$ ) but was relatively stable in the $3 \times$ quarters (time $\times$ treatment; $P>0.15$ ). Thus, CSN2 mRNA was more abundant in the $3 \times$ quarters than in the $1 \times$ quarters in wk 4 and 8 . The expression of both IGF1 and IGF1R (insulin-like growth factor 1 receptor) was higher in the $3 \times$ quarters than in the $1 \times$ quarters in wk 4 of treatment, whereas no differences in IGFBP5 (insulin-like growth factor binding protein 5 ) expression were observed. In wk 4 and 8 , the expression of both PRLR (prolactin receptor) isoforms and of $S T C 1$ was significantly higher in the $3 \times$ quarters than in the $1 \times$ quarters. The expression of PTHLH (parathyroid hormone-like hormone) increased with time in the $3 \times$ quarters (time $\times$ treatment; $P<0.01$ ), whereas it decreased in the $1 \times$ quarters (time $\times$ treatment; $P<0.05)$. Also, the expression of the $M Y C$ gene (c-Myc) increased with time in the $1 \times$ quarters (time $\times$ treatment; $P<0.05)$ but was relatively stable in the $3 \times$ quarters (time $\times$ treatment; $P>0.15$ ). Thus, the $1 \times$ quarters expressed more $M Y C$ than the $3 \times$ quarters in wk 8. Expression of $B A X$ (Bcl2-associated $\mathrm{X}$ protein) was similar in both glands, whereas expression of BCL2 (B-cell CLL/lymphoma 2) was higher in the $1 \times$ quarters at wk 8 . Consequently, the $B A X: B C L 2$ mRNA ratio was lower in the $1 \times$ quarters than in the $3 \times$ quarters in wk 8 of treatment.

\section{DISCUSSION}

In the present experiment, mid-lactation cows were milked at different frequencies according to a half-udder model to characterize the effects of milking frequency on the mammary gland and on the production and composition of milk. This study was also designed to identify factors that may be implicated in the modulation of lactation persistency.

In agreement with previous studies, $1 \times$ milking reduced milk yield (O'Brien et al., 2002), whereas $3 \times$ milking increased it (Hale et al., 2003). After 8 wk of treatment, $2 \times$ milking was resumed and an important, although partial, difference in yield remained between the gland pairs that had been milked at different frequencies. Interestingly, the milk yield of the $3 \times$ gland pairs was numerically higher $(0.8 \mathrm{~kg} / \mathrm{d})$ during the first week of posttreatment than the average production measured during the pretreatment period, even though it was more than 2 mo later. Although in agreement with the work of Elliott (1961), this positive effect of $3 \times$ milking on persistency is in discrepancy with a recent review by Wall and McFadden (2008), which stated that 


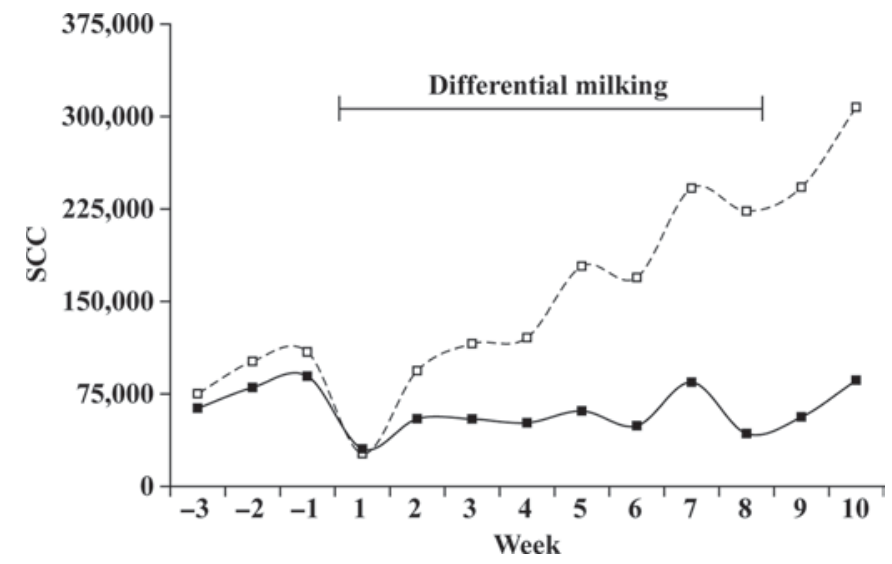

Figure 3. Effect of differential milking on milk SCC (cells $/ \mathrm{mL}$ ) in quarters milked once $(1 \times ; \square$, dashed line) or thrice $(3 \times ; \mathbf{\square}$, solid line) daily from wh 1 to 8 and twice daily before and after the differential milking period. The $1 \times$ quarters had higher milk SCC than the $3 \times$ quarters during $(P<0.05)$ and after $(P<0.01)$ differential milking. Data were $\log _{10}$-transformed before statistical analysis and are presented as the antilog values of the calculated means.

the positive carryover effect of IMF is limited to early lactation. It therefore seems that at any stage of lactation differential milking may have 2 important effects on lactation: an immediate but sustained modulation of milk production and a longer term effect on lactation persistency. It is important to note that reduced milking frequency in one gland pair could have increased the nutrients available for the other half. This could have had a positive effect on milk production. However, the carryover effect caused by $3 \times$ milking strongly suggests that nutrient availability is not solely responsible for the positive effects of IMF.

Once-daily milking had numerous other effects on the mammary gland. Milk BSA concentration increased rapidly when milking frequency changed, whereas lactose concentration decreased. Consequently, it seems that $1 \times$ milking led to an increase in the permeability of the mammary epithelium. This was probably caused by an increase in the leakiness of the tight junctions. As discussed by Stelwagen (2001), this permeability change could be responsible for the rapid decrease in milk yield observed upon initiation of $1 \times$ milking. Although BSA concentrations declined when milking frequency increased from $1 \times$ to $2 \times$, it remained higher than in the milk from the half gland previously milked $3 \times$. A carryover effect was also observed by Stelwagen and Lacy-Hulbert (1996). Similarly, SCC remained elevated in milk from these quarters. Diapedesis of immune cells will disturb epithelial cell integrity and probably provide opportunities for BSA to diffuse into milk. Accordingly, mammary inflammation causes a sharp increase in milk concentration of BSA (Bouchard et al., 1999).
Once-daily milking increased mammary cell apoptosis and, surprisingly, also mammary cell proliferation. Mammary gland expression of the $M Y C$ gene was also upregulated, and given that the product of this gene can promote mammary cell proliferation, the $M Y C$ gene product may have played an important role in the observed increase in cell proliferation. To our knowledge, this is the first report indicating that an increased rate of mammary cell proliferation is induced by reduced milking frequency. However, $1 \times$ milking seems to have led to a net loss of mammary tissue. Indeed, visual inspection of the quarters after milking revealed an obvious reduction in the size of the $1 \times$ quarters. During the entire posttreatment period (after $2 \times$ milking had been resumed), the quarters that had previously been milked $1 \times$ were still smaller than those that had been milked $3 \times$. Thus, mammary cell loss is probably responsible for the negative effect of $1 \times$ milking on lactation persistency. Reduced mammary secretory activity could also have contributed to this effect, given that CSN2 expression was decreased during the $1 \times$ milking. However, this reduced gene expression could also be the consequence of the loss of secretory cells.

Milk gelatinase activity of MMP also increased during $1 \times$ milking. Substrates of these proteases include several extracellular matrix components present in the mammary gland (Chakraborti et al., 2003). Therefore, the increase in MMP activities was probably involved in the remodeling of the mammary gland. It is important to mention that inhibition of the MMP by inhibitors is lost during zymography (Snoek-van Beurden and Von den Hoff, 2005); consequently, the measured MMP activities could be different from the actual in

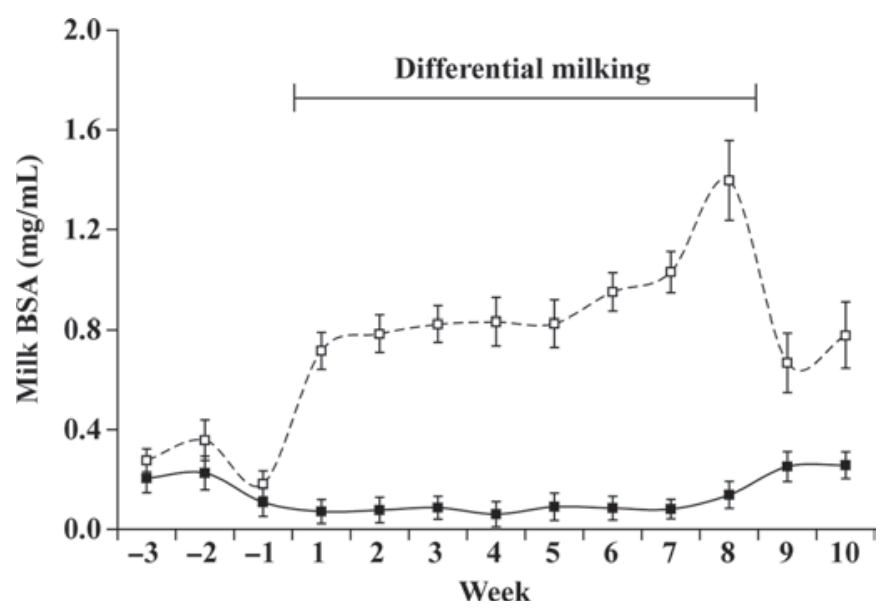

Figure 4. Effect of differential milking on milk BSA concentration in quarters milked once $(1 \times ; \square$, dashed line) or thrice $(3 \times$; $\mathbf{\square}$, solid line) daily from wk 1 to 8 and twice daily before and after the differential milking period. Milk BSA concentration was higher in the $1 \times$ quarters than in the $3 \times$ quarters during and after differential milking $(P<0.001)$, and to a lesser extent, in the pretreatment period $(P<$ $0.05)$. Data are presented as least squares means \pm SEM. 

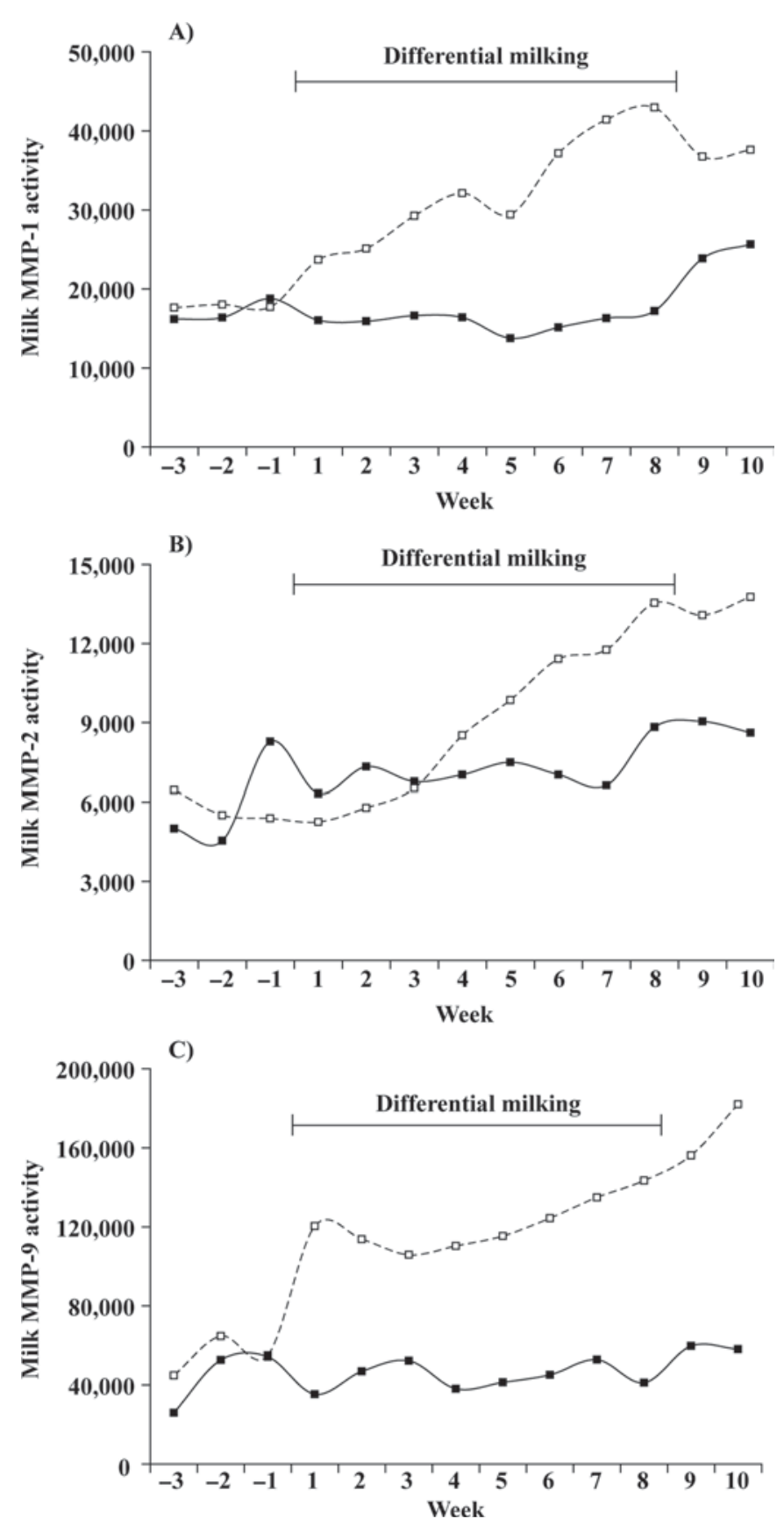

Figure 5. Effect of differential milking on milk matrix metalloproteinase (MMP) activities. Activity of A) MMP-1, B) MMP-2, and C) MMP-9 in milk obtained from quarters milked once $(1 \times ; \square$, dashed line) or thrice $(3 \times$;, solid line) daily from wk 1 to 8 and twice daily before and after the differential milking period. The activity of MMP1 and MMP-9 was higher in the $1 \times$ milk than in the $3 \times$ milk during and after differential milking $(P<0.01)$. Differences in milk MMP-2 activities were observed in wk $6(P<0.05)$ and $7(P<0.01)$, whereas a trend was apparent in wk $8(P=0.07)$. Data are presented as least squares means. vivo activities. Interestingly, milk MMP activities, BSA concentration (Tremblay et al., 2009), and mammary cell proliferation (Capuco et al., 1997) and apoptosis (Nørgaard et al., 2008) are similarly increased during the mammary gland remodeling that occurs during the dry period. Given that these parameters were also increased by $1 \times$ milking in this study, it seems that a similar mammary gland remodeling was induced by $1 \times$ milking.

Another interesting event that took place in the $1 \times$ quarters was a decrease in $I G F 1 R$ expression. Although the expression of IGF1 and IGFBP5 genes or changes in milk IGF-I concentration cannot explain the effect of $1 \times$ milking on production and persistency, the expression of this IGF-I receptor could. It has been demonstrated that IGF-I protects various cell types against multiple apoptotic stimuli, including tumor necrosis factor- $\alpha$ (TNF- $\alpha$ ) and Fas ligand (FasL), mainly by activating PI3K/AKT and ERK1/2 (Kurmasheva and Houghton, 2006). Interestingly, the mammary gland expression of both TNF- $\alpha$ and FasL is upregulated during mouse mammary gland involution induced by milk stasis (Watson, 2006). Similarly, it appears that c-Myc may induce apoptosis, which can be inhibited by IGF-I under certain conditions (Harrington et al., 1994; Hueber et al., 1997). Although not evaluated in this study, the increased expression of $M Y C$ and possibly of TNF and FASLG (genes encoding TNF- $\alpha$ and FasL, respectively), coupled with reduced IGF-I responsiveness, may have played an important role in the loss of mammary tissue in the $1 \times$ quarters. Therefore, the decreased expression of $I G F 1 R$ could be implicated in the reduced persistency of the $1 \times$ quarters.

Milking $3 \times$ had more limited effects on several parameters than did milking $1 \times$. For example, milk MMP activities, lactose concentration, and mammary cell proliferation and apoptosis were unaffected by $3 \times$ milking. However, unlike $1 \times$ milking, $3 \times$ milking decreased milk BSA concentration, although BSA concentration returned to pretreatment values when $2 \times$ milking was reinitiated. This result suggests that frequent milking reduces tight junction leakiness and could have had a positive effect on milk yield. Accordingly, Sorensen et al. (2001) observed better epithelial integrity in half glands milked $3 \times$ compared with half glands milked $2 \times$.

Given that milk production is a function of the number of mammary epithelial cells and their secretory activity, one or both parameters must have been positively affected by IMF. The increased secretory activity likely contributed to the rapid increase in milk production during $3 \times$ milking, given that CSN2 expression was upregulated by this treatment. Despite the fact that we have not been able to show a clear effect 


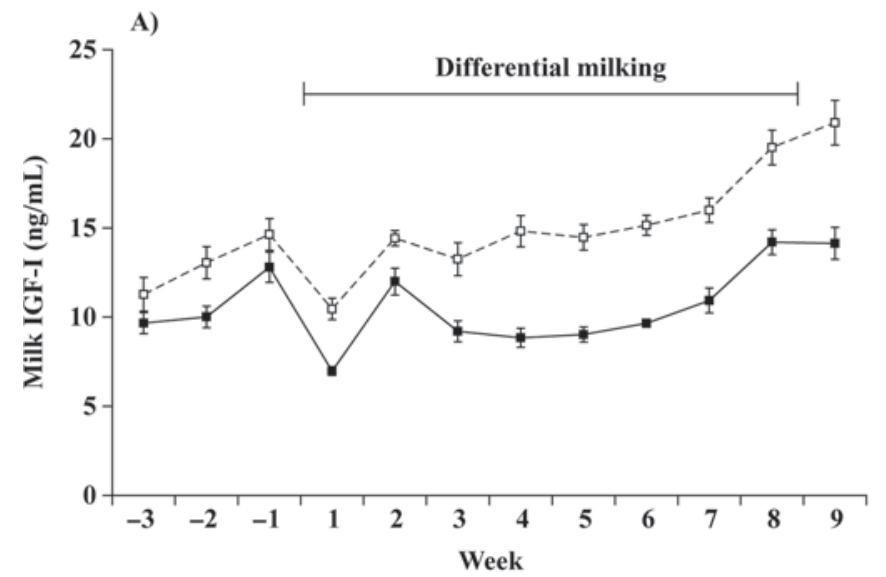

B)

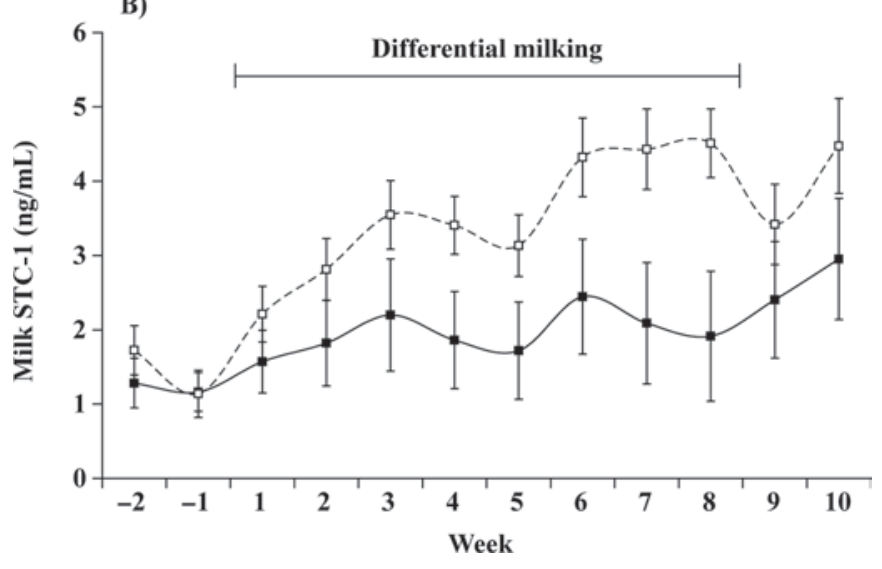

Figure 6. Effect of differential milking on milk IGF-I (panel A) and stanniocalcin-1 (STC-1, panel B) concentrations in milk obtained from quarters milked once $(1 \times ; \square$, dashed line) or thrice $(3 \times$; $\mathbf{\square}$, solid line) daily from wk 1 to 8 and twice daily before and after the differential milking period. Milk IGF-I and STC-1 concentrations were higher in the $1 \times$ quarters than in the $3 \times$ quarters during (IGF-I, $P<$ 0.0001; STC-1, $P<0.01$ ) and after differential milking (IGF-I, $P<$ 0.001 ; STC-1, $P<0.01)$. Milk IGF-I concentration was already higher in those quarters before treatment $(P<0.05)$. Data are presented as least squares means \pm SEM.

of $3 \times$ milking on mammary proliferation and apoptosis, a reduction of the net loss of secretory cells during the 8 wk of treatment probably contributed to the positive effect of IMF on lactation persistency. However, with only the present data we cannot rule out the possibility that increased mammary cell secretory activity may also have contributed to this effect.

Although the expression of both PRLR isoforms was higher in the $3 \times$ quarters, the role of prolactin (PRL) in lactating dairy ruminants is a matter of debate. Plaut et al. (1987) reported that the administration of pharmacological doses of PRL did not affect milk yield. In older studies, short-term inhibition of PRL secretion by CB154 resulted in little or no effect on milk yield (Karg and Schams, 1974). Nevertheless, Lacasse et al. (2008) recently found that treating cows for a longer period with quinagolide, a powerful PRL-release inhibi-
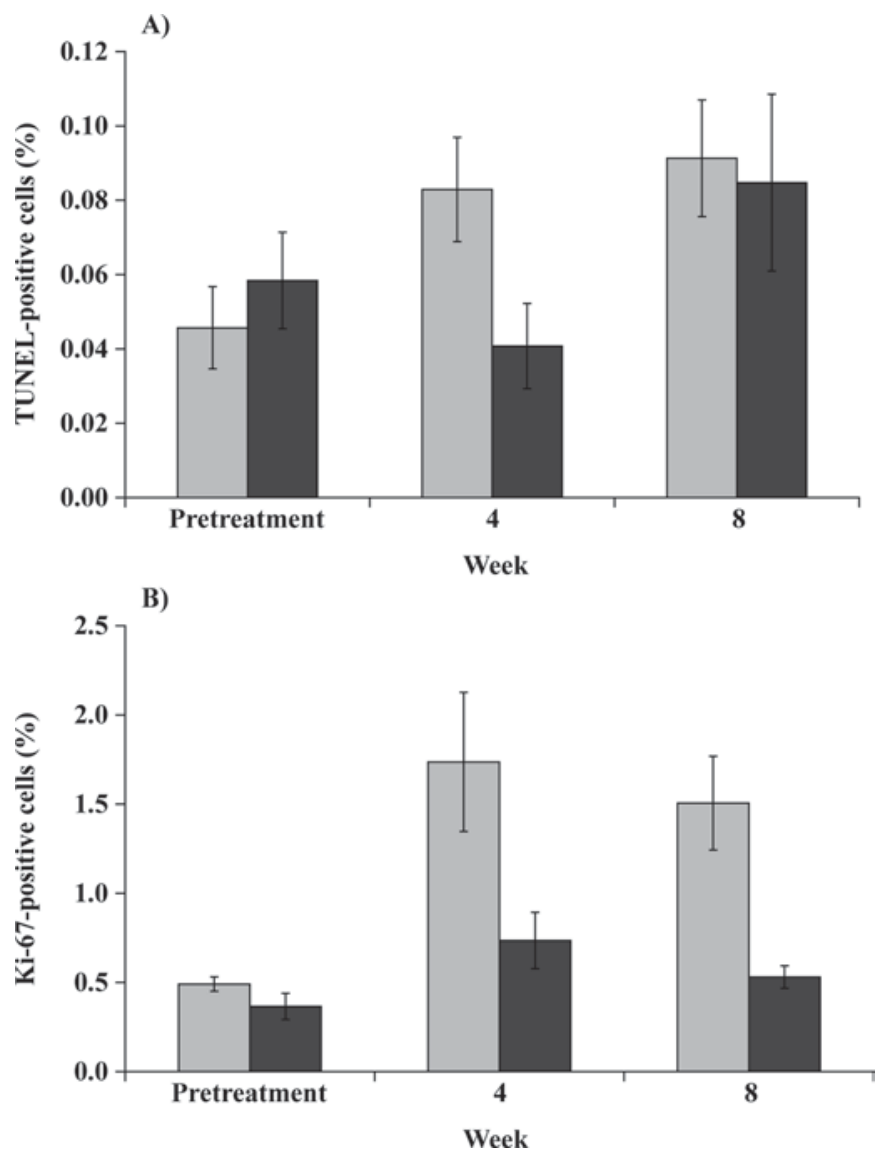

Figure 7. Effect of differential milking on apoptosis (A; terminal deoxynucleotidyl transferase dUTP nick-end labeling, TUNEL) and proliferation (B; Ki-67 labeling) rates of mammary cells obtained from quarters milked once $(1 \times$; gray bars) or thrice $(3 \times$; black bars) daily during the differential milking period and twice daily during the pretreatment period, with biopsies taken in wk $-1,4$, and 8 . Data are presented as the percentage of labeled cells compared with the total number of cells. Apoptosis was higher in the $1 \times$ quarters than in the $3 \times$ quarters in wk $4(P<0.05)$, whereas proliferation was higher in wk $4(P<0.05)$ and wk $8(P<0.01)$. Data are presented as least squares means \pm SEM.

tor, reduces milk production. Those authors also found that, when combined with differential milking (half of the gland milked $2 \times$ and the other half milked $1 \times$ ), quinagolide loses its inhibitory effect in the $1 \times$ glands. This result suggests there is a link between the effect of PRL and milking frequency, as supported by the present data. Moreover, if PRL acts as a galactopoietic hormone in cows, higher responsiveness to PRL caused by upregulated PRLR expression could have resulted in increased mammary cell secretory activity and lactation persistency. Therefore, the upregulation of $P R L R$ isoforms could be critical for the positive effects of IMF.

In accordance with a previous study (Miller et al., 2006), we observed an increase in milk STC-1 concentration as lactation progressed. Moreover, this increase 
Table 2. Gene expression in the mammary glands of lactating cows milked at different frequencies ${ }^{1}$

\begin{tabular}{|c|c|c|c|c|c|c|c|c|c|}
\hline Gene $^{2}$ & \multicolumn{3}{|c|}{ Pretreatment } & \multicolumn{3}{|c|}{ Week 4} & \multicolumn{3}{|c|}{ Week 8} \\
\hline$B A X$ & 1.019 & 0.959 & 0.323 & 0.949 & 1.273 & 0.308 & 1.286 & 1.174 & 0.387 \\
\hline CSN2 & 1.239 & 1.199 & 0.092 & 0.834 & $1.603^{* * *}$ & 0.153 & 0.483 & $1.286^{* * *}$ & 0.193 \\
\hline$I G F 1$ & 0.820 & 0.833 & 0.108 & 0.825 & $1.265^{*}$ & 0.195 & 1.450 & 1.020 & 0.286 \\
\hline IGFIR & 0.594 & 0.556 & 0.111 & 0.292 & $0.530^{*}$ & 0.121 & 0.308 & $0.505 \dagger$ & 0.130 \\
\hline PRLR (short) & 0.897 & $0.766^{*}$ & 0.078 & 0.704 & $0.943^{* *}$ & 0.091 & 0.646 & $0.954^{* *}$ & 0.111 \\
\hline PRLR (long) & 0.779 & 0.690 & 0.061 & 0.724 & $0.893^{*}$ & 0.064 & 0.699 & $0.965^{*}$ & 0.106 \\
\hline PTHLH & 1.203 & 1.131 & 0.125 & 0.983 & $1.780^{* * *}$ & 0.179 & 0.485 & $1.309^{* * *}$ & 0.191 \\
\hline$S T C 1$ & 1.219 & 1.150 & 0.108 & 0.902 & $1.686^{* * *}$ & 0.136 & 1.158 & $1.995^{* *}$ & 0.232 \\
\hline$B A X: B C L 2$ & 0.873 & $1.064 \dagger$ & 0.136 & 0.871 & 1.053 & 0.175 & 0.515 & $1.006^{* * *}$ & 0.141 \\
\hline
\end{tabular}

${ }^{1}$ Mammary biopsies were taken on hindquarters in the indicated week (pretreatment corresponds to wk -1 ). Quarters were milked twice daily $(2 \times)$ during the pretreatment period and either once $(1 \times)$ or thrice daily $(3 \times)$ during the differential milking period (wk 4 and 8 ). All values were normalized with the $A C T G 1 \mathrm{cDNA}$ and $\log _{10}$ transformed.

${ }^{2} A C T G 1=$ actin; $B A X=$ Bcl2-associated X protein; $B C L 2=$ B-cell CLL/lymphoma $2 ; C S N 2=\beta$-casein; IGF1 = insulin-like growth factor $1 ;$ $I G F 1 R=$ insulin-like growth factor 1 receptor; IGFBP $5=$ insulin-like growth factor binding protein $5 ; M Y C=\mathrm{c}-\mathrm{Myc} ; P R L R$ (short) = prolactin receptor, short isoform; PRLR (long) = prolactin receptor, long isoform; $P T H L H=$ parathyroid hormone-like hormone $(\mathrm{PTHrP}) ; S T C 1=$ stanniocalcin-1; $B A X: B C L 2=B A X$ to $B C L 2$ mRNA expression ratio.

$\dagger P<0.10 ;{ }^{*} P<0.05 ;{ }^{*} P<0.01 ;{ }^{* * *} P<0.001$ indicate differences between left and right hindquarters.

was higher in the $1 \times$ milk than in the $3 \times$ milk. Previous studies also showed that prolonged milk stasis increases the concentration of this calcium-regulating hormone in milk (Tremblay et al., 2009). Similarly, in response to injections of $17 \beta$-estradiol (Delbecchi et al., 2005), which led to important reductions in milk production, milk concentration of STC-1 was increased. Consequently, the elevated STC-1 concentrations in $1 \times$ milk could be related to the decrease in milk yield, mammary gland remodeling, or both. Thus, we suspect that STC-1 could be a negative regulator of lactation. Mammary STC1 expression levels did not correlate with its concentration in the milk, suggesting that blood-borne STC-1 is present in milk. Interestingly, milking frequency also modulated the expression of another calcium-regulating hormone. Although $1 \times$ milking decreased mammary gland expression of the gene encoding the parathyroid hormone-related protein (PTHrP; PTHLH gene), the expression of that gene was increased during $3 \times$ milking. Thompson et al. (1994) reported a similar modulation of PTHrP in goats milked unilaterally $1 \times$ and $4 \times$. Several functions have been proposed for this hormone in the mammary gland (Philbrick et al., 1996) but the observed modulation of its expression by milking frequency was likely a response to a change in the calcium requirement for milk production. Interestingly, STC-1 and PTHrP could play opposing roles in this process, given that it was recently shown that STC-1 can inhibit some of the effects of PTHrP in fish (Wever et al., 2007). Stelwagen and Callaghan (2003) reported that PTHrP plays a role in the maintenance of the mammary tight junctions. Interestingly, a negative relationship between PTHLH gene expression and tight junction permeability was observed in the present study.

Because the $B A X: B C L 2$ expression ratio is often used as an indicator of cell susceptibility to apoptosis (Perlman et al., 1999; Nørgaard et al., 2008), the expression levels of both genes were evaluated. Interestingly, their ratios did not correlate with the apoptosis rate measured by TUNEL assay. Given that the TUNEL assay is a more direct measurement of apoptosis, it seems that the $B A X: B C L 2$ ratio gave an inaccurate indication of cell susceptibility to apoptosis. Considering the large number of Bcl-2 family members regulating apoptosis, this is not a surprising result. The $B A X: B C L 2$ ratio should therefore be interpreted with caution.

This study has shown that milking frequency modulates both milk yield and lactation persistency in mid-lactation cows. Interestingly, milking $1 \times$ seems to increase mammary remodeling. Our results also suggest that milking frequency may affect mammary gland responsiveness to endocrine factors such as PRL and IGF-I. However, information is still lacking on the local mediators that link the frequency of milk removal and the events observed at the cellular level. The involvement of factors such as STC-1 and the implications of mammary gland permeability are possible but not yet proven. In conclusion, the results of this study suggest that the management of milking frequency has the potential to be beneficial not only during early lactation but also later in lactation. 


\section{ACKNOWLEDGMENTS}

The authors thank all those at the Dairy and Swine Research and Development Centre that have contributed to this research, including Jasmin Brochu and Benoit Pouliot for providing technical assistance, the dairy barn staff in Lennoxville for taking care of the cows, and Steve Méthot for performing the statistical analysis. Also, we thank the National Hormone and Peptide Program and A. F. Parlow for the IGF-I antiserum. This research was financially supported by Dairy Farmers of Canada, Agriculture and Agri-Food Canada, the National Sciences and Engineering Research Council of Canada, and the Canadian Institutes of Health Research.

\section{REFERENCES}

Abribat, T., P. Brazeau, I. Davignon, and D. R. Garrel. 1993. Insulinlike growth factor-I blood levels in severely burned patients: Effects of time post injury, age of patient and severity of burn. Clin. Endocrinol. (Oxf.) 39:583-589.

Bouchard, L., S. Blais, C. Desrosiers, X. Zhao, and P. Lacasse. 1999. Nitric oxide production during endotoxin-induced mastitis in the cow. J. Dairy Sci. 82:2574-2581.

Capuco, A. V., R. M. Akers, and J. J. Smith. 1997. Mammary growth in Holstein cows during the dry period: Quantification of nucleic acids and histology. J. Dairy Sci. 80:477-487.

Capuco, A. V., D. L. Wood, R. Baldwin, K. Mcleod, and M. J. Paape. 2001. Mammary cell number, proliferation, and apoptosis during a bovine lactation: Relation to milk production and effect of bST. J. Dairy Sci. 84:2177-2187.

Chakraborti, S., M. Mandal, S. Das, A. Mandal, and T. Chakraborti. 2003. Regulation of matrix metalloproteinases: An overview. Mol. Cell. Biochem. 253:269-285.

Delbecchi, L., N. Miller, C. Prud'homme, D. Petitclerc, G. F. Wagner, and P. Lacasse. 2005. 17ß-estradiol reduces milk synthesis and increases stanniocalcin gene expression in the mammary gland of lactating cows. Livest. Prod. Sci. 98:57-66.

Elliott, G. M. 1961. The effect on milk yield of three times a day milking and of increasing the level of residual milk. J. Dairy Res. 28:209-219.

Erdman, R. A., and M. Varner. 1995. Fixed yield responses to increased milking frequency. J. Dairy Sci. 78:1199-1203.

Hale, S. A., A. V. Capuco, and R. A. Erdman. 2003. Milk yield and mammary growth effects due to increased milking frequency during early lactation. J. Dairy Sci. 86:2061-2071.

Harrington, E. A., M. R. Bennett, A. Fanidi, and G. I. Evan. 1994 c-Myc-induced apoptosis in fibroblasts is inhibited by specific cytokines. EMBO J. 13:3286-3295.

Hueber, A. O., M. Zörnig, D. Lyon, T. Suda, S. Nagata, and G. I. Evan. 1997. Requirement for the CD95 receptor-ligand pathway in c-Myc-induced apoptosis. Science 278:1305-1309.

Karg, H., and D. Schams. 1974. Prolactin release in cattle. J. Reprod. Fertil. 39:463-472.

Kurmasheva, R. T., and P. J. Houghton. 2006. IGF-I mediated survival pathways in normal and malignant cells. Biochim. Biophys. Acta 1766:1-22.

Lacasse, P., V. Lollivier, R. M. Bruckmaier, Y. R. Boisclair, G. W. Wagner, and M. Boutinaud. 2008. Effect of the prolactinrelease inhibitor Quinagolide on dairy cows. J. Dairy Sci. 91(E-Suppl. 1):379. (Abstr.)

Miller, N., L. Delbecchi, D. Petitclerc, G. F. Wagner, B. G. Talbot, and P. Lacasse. 2006. Effect of stage of lactation and parity on mammary gland cell renewal. J. Dairy Sci. 89:4669-4677.
Niu, P., D. P. Radman, E. M. Jaworski, H. Deol, R. Gentz, J. Su, H. S. Olsen, and G. F. Wagner. 2000. Development of a human stanniocalcin radioimmunoassay: Serum and tissue hormone levels and pharmacokinetics in the rat. Mol. Cell. Endocrinol. 162:131144.

Nørgaard, J., A. Sørensen, M. T. Sørensen, J. B. Andersen, and K. Sejrsen. 2005. Mammary cell turnover and enzyme activity in dairy cows: Effects of milking frequency and diet energy density. J. Dairy Sci. 88:975-982.

Nørgaard, J. V., P. K. Theil, M. T. Sørensen, and K. Sejrsen. 2008. Cellular mechanisms in regulating mammary cell turnover during lactation and dry period in dairy cows. J. Dairy Sci. 91:23192327.

O'Brien, B., G. Ryan, W. J. Meaney, D. McDonagh, and A. Kelly. 2002. Effect of frequency of milking on yield, composition and processing quality of milk. J. Dairy Res. 69:367-374.

Perlman, H., X. Zhang, M. W. Chen, K. Walsh, and R. Buttyan. 1999. An elevated bax/bcl-2 ratio corresponds with the onset of prostate epithelial cell apoptosis. Cell Death Differ. 6:48-54.

Philbrick, W. M., J. J. Wysolmerski, S. Galbraith, E. Holt, J. J. Orloff, K. H. Yang, R. C. Vasavada, E. C. Weir, A. E. Broadus, and A. F. Stewart. 1996. Defining the roles of parathyroid hormone-related protein in normal physiology. Physiol. Rev. 76:127-173.

Plaut, K., D. E. Bauman, N. Agergaard, and R. M. Akers. 1987. Effect of exogenous prolactin administration on lactational performance of dairy cows. Domest. Anim. Endocrinol. 4:279-290.

Raulo, S. M., T. Sorsa, T. Tervahartiala, T. Latvanen, E. Pirilä, J. Hirvonen, and P. Maisi. 2002. Increase in milk metalloproteinase activity and vascular permeability in bovine endotoxin-induced and naturally occurring Escherichia coli mastitis. Vet. Immunol. Immunopathol. 85:137-145.

Snoek-van Beurden, P. A., and J. W. Von den Hoff. 2005. Zymographic techniques for the analysis of matrix metalloproteinases and their inhibitors. Biotechniques 38:73-83.

Sorensen, B. A., D. D. Muir, and C. H. Knight. 2001. Thrice-daily milking throughout lactation maintains epithelial integrity and thereby improves milk protein quality. J. Dairy Res. 68:15-25.

Stelwagen, K. 2001. Effect of milking frequency on mammary function and shape of the lactation curve. J. Dairy Sci. 84(E Suppl.):E204E211.

Stelwagen, K., and M. R. Callaghan. 2003. Regulation of mammary tight junctions through parathyroid hormone-related peptideinduced activation of apical calcium channels. J. Endocrinol. $178: 257-264$.

Stelwagen, K., and C. H. Knight. 1997. Effect of unilateral once or twice daily milking of cows on milk yield and udder characteristics in early and late lactation. J. Dairy Res. 64:487-494.

Stelwagen, K., and J. Lacy-Hulbert. 1996. Effect of milking frequency on milk somatic cell count characteristics and mammary secretory cell damage in cows. Am. J. Vet. Res. 57:902-905.

Thompson, G. E., W. A. Ratcliffe, S. Hughes, S. K. Abbas, and A. D. Care. 1994. Local control of parathyroid hormone-related protein secretion by the mammary gland of the goat. Comp. Biochem. Physiol. Comp. Physiol. 108:485-490.

Tremblay, G., P. Bernier-Dodier, L. Delbecchi, G. F. Wagner, B. G. Talbot, and P. Lacasse. 2009. Local control of mammary involution: Is stanniocalcin-1 involved? J. Dairy Sci. 92:1998-2006.

Wall, E. H., and T. B. McFadden. 2007. Optimal timing and duration of unilateral frequent milking during early lactation of dairy cows. J. Dairy Sci. 90:5042-5048.

Wall, E. H., and T. B. McFadden. 2008. Use it or lose it: Enhancing milk production efficiency by frequent milking of dairy cows. J. Anim. Sci. 86(13 Suppl.):27-36.

Watson, C. J. 2006. Post-lactational mammary gland regression: Molecular basis and implications for breast cancer. Expert Rev. Mol. Med. 8:1-15.

Wever, K. E., R. Masereeuw, D. S. Miller, X. M. Hang, and G. Flik 2007. Endothelin and calciotropic hormones share regulatory pathways in multidrug resistance protein 2-mediated transport. Am. J. Physiol. Renal Physiol. 292:F38-F46. 